\title{
Interaction of Porphyrins and Porphyrin Analogs with Coordinating Organic Solvents
}

\author{
Dmitry B. Berezin ${ }^{@}$ and Dmitry R. Karimov \\ Ivanovo State University of Chemistry and Technology, Ivanovo, 153000, Russia \\ @Corresponding authorE-mail: berezin@isuct.ru
}

\begin{abstract}
Chemical interaction "porphyrin-solvent" between the reaction center of basic solvent and weakly acidic macrocyclic $\mathrm{NH}$ group is analyzed for different types of porphyrin ligands $\left(\mathrm{H}_{2} \mathrm{P}\right)$. Planar and distorted ligands, common $\mathrm{H}_{2} \mathrm{P}$ and porphyrin analogs are considered using spectrophotometric titration, kinetic measurements, ${ }^{1} H$ NMR and fluorescent spectroscopy as well as quantum-chemical calculations. Reaction is usually reversible for non-planar compounds and proceeds in kinetic regime in the case of $\mathrm{H}_{2} \mathrm{P}$ with more rigid aromatic structure like porphyrazines. Deepening of the saddle non-planar conformation favors formation of $H$-associates as compared to other distorted types of porphyrins (ruffle, wave, stepped, etc.) due to polarization of saddle structure. In dependence on the class of $\mathrm{H}_{2} \mathrm{P}$ analogs they either, like corroles, repeat behavior of saddle non-planar common porphyrins, or undergo some kind of specific transformations like tautomerism of inverted $\mathrm{H}_{2} \mathrm{P}$ analogs. Addition of a stronger base like diethylamine or piperidine to solution of $\mathrm{H}$-associate in polar donating solvent usually results in formation of porphyrin monoanion.
\end{abstract}

Keywords: Porphyrins, porphyrin analogs, macrocyclic effect, acid-base H-associates, NH-reactivity criteria.

\section{Introduction}

Porphyrins and their analogs $\left(\mathrm{H}_{2} \mathrm{P}\right.$, compounds $\left.\mathbf{I}-\mathbf{X X}\right)$ are known as highly aromatic and at the same time flexible macroheterocyclic ligands. ${ }^{[1]}$ On one hand their aromaticity is confirmed by theoretical calculations (Nuclear Independent Chemical Shifts, NICS, Harmonic Oscillator Model of Aromaticity, HOMA, and other quantitative criteria ${ }^{[2]}$ ), high magnetic anisotropy ${ }^{[3]}$ and thermal stability, ${ }^{[4]}$ etc. Their ability to change structure and to adopt one of the typical non-planar conformations in both crystal and liquid phase $\mathrm{e}^{[1]}$ can be used as an unique possibility to regulate reactivity of these compounds like it occurs in nature. Studies of last two-three decades show that namely conformational transformations of complex biomolecules including porphyrins in vivo are responsible for the exertion of their biological activity caused by structural and external changes of molecular environment. ${ }^{[5]}$

This paper is devoted to the investigation of the porphyrin interaction with electron-donating solvents in connection with some other aspects of their reactivity. This is a way to stress interrelation between spatial structure and chemical properties of porphyrin macromolecules.

Interaction of porphyrins with coordinating solvents is not a common property for all classes of tetrapyrrolic macrocycles. Porphyrinoid macrocycles can be classified for common porphyrins (I-XVI) and porphyrin analogs, for instance, XVII-XX ${ }^{[6,7]}$ Porphyrin analogs differ from common porphyrins by the structure of coordination core dissimilar to $\mathrm{H}_{2} \mathrm{P}\left(\mathrm{N}_{4} \mathrm{H}_{2}\right)$ and (or) different type of $\mathrm{C}_{\alpha}-\mathrm{C}_{\alpha}$ bonding between pyrrolic or another aromatic units. ${ }^{[7]}$ Most typical classes of porphyrin-like analogs are $\mathrm{N}$-substituted, ${ }^{[8]}$ expanded $^{[9]}$ and heteroatom-substituted ${ }^{[10]}$ compounds, porphyrin isomers ${ }^{[11]}$ and carbaporphyrins ${ }^{[12]}$ including inverted porphyrin analogs ( $\mathbf{X V I I - X V I I I )})^{[13]}$ as well as corroles (XIX-XXX) ${ }^{[14]}$ and some other macrocycles. Their interaction with a solvent is mostly a subject of the further investigations, however some examples are known ${ }^{[15-19]}$ and will be discussed in this paper.

As for common porphyrins, they can be formally divided into three group $\mathrm{S}^{[7,20]}$ with characteric basic structural features. Compounds of the first group are mainly planar $\beta$ and meso-substituted porphyrins and chlorins. The second group includes highly aromatic compounds, mainly porphine and porphyrazine derivatives with four $\beta, \beta$ '-fused aromatic rings as well as porphyrazines themselves. The third group of compounds contains $\mathrm{H}_{2} \mathrm{P}$ with a highly non-planar structure which nevertheless remains aromatic. ${ }^{[5]}$

Highly distorted common porphyrins compose extended group of compounds. ${ }^{[5,7]}$ Within them macrocycles can be divided into several modifications which possess different types and degrees of non-planarity. Such a distorted structure can be reached with: 1) modification of the porphyrin periphery like simultaneous $\beta$ - and mesomultisubstitution (IX, XI-XIII), tetra-meso-substitution with bulky groups (XIV-XVI), fitted with shortened spacers in the case of monomer or dimer formation, etc.; 2) modification of coordination core as in the case of substitution on inner-cyclic NH-groups, ${ }^{[8]} \mathrm{H}_{2} \mathrm{P}$ mono- and diacids formation, porphyrin complexation with metals with ionic radii higher or lower than the size of the $\mathrm{N}_{4}$ coordination cavity, etc.; 3) ligand modification leading to decrease of its aromaticity, for instance, in the case of $\pi$-cation-radicals formation, or to diminishing of the $\pi$-system size due to $\beta, \beta$ '-reduction in chlorins, etc.; 4) simultaneous effect of two or more above factors. In this paper only distortion effects of dodeca-, meso- and inner-cyclic N-substitution will be considered. 


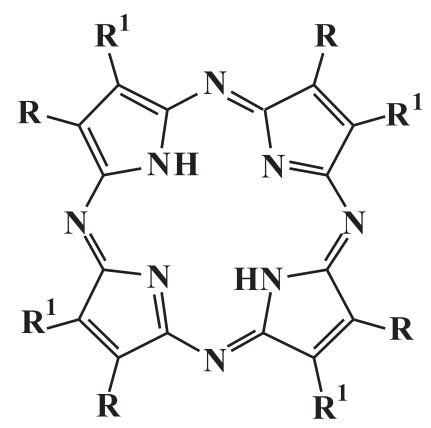

I. $\mathrm{R}=\mathrm{R}^{1}=\mathrm{H}$;

II. $\mathrm{R}=\mathrm{R}^{1}=\mathrm{Ph}$;

III. $\mathrm{R}=\mathrm{R}^{1}=(p-\mathrm{Br}) \mathrm{Ph}$;

IV. $\mathrm{R}=\mathrm{R}^{1}=\left(p-\mathrm{NO}_{2}\right) \mathrm{Ph}$;

V. $\mathrm{R}=\mathrm{Br}, \mathrm{R}^{1}=\mathrm{H}$;

VI. $\mathrm{R}=\mathrm{Cl}, \mathrm{R}^{1}=\mathrm{H}$

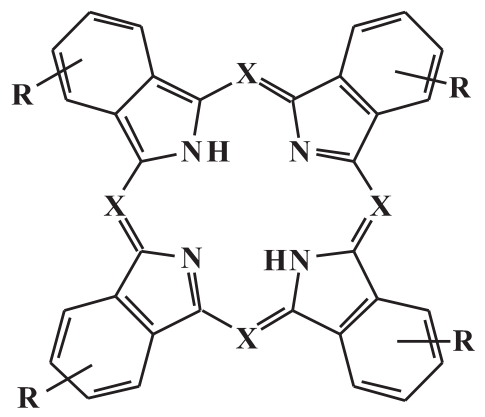

VII. $\mathrm{X}=\mathrm{N}, \mathrm{R}=$ tert -Bu;

VIII. $\mathrm{X}=\mathrm{CH}, \mathrm{R}=\mathrm{H}$;

IX. $\mathrm{X}=\mathrm{C}-\mathrm{Ph}, \mathrm{R}=\mathrm{H}$

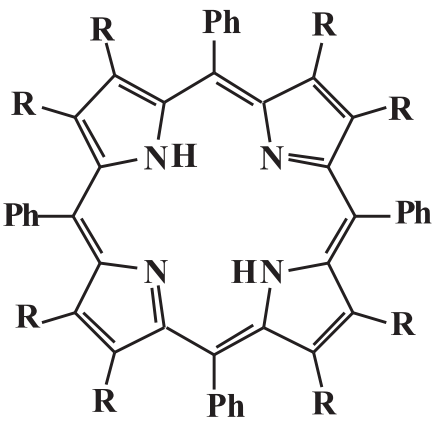

X. $\mathrm{R}=\mathrm{H}$;

XI. R = Et;

XII. $\mathrm{R}=\mathrm{Ph}$;

XIII. $\mathrm{R}=\mathrm{Br}$<smiles></smiles>

XIV. R = iso-Pr;

XV. R = cyclo-Hex;

XVI. R = tert $-\mathrm{Bu}$

Acid-basic interaction is a complex process which consists of a number of steps with a variable degree of proton transfer from the acidic to basic reaction center, so called "protonation depth". ${ }^{[21]}$ For common porphyrin monoand dianionic species are the final ones. In these species one or two of $\mathrm{NH}$ bonds respectively are broken and full proton transfer is realized (Equation 1). ${ }^{[22]}$

$$
\begin{aligned}
& \mathrm{H}_{2} \mathrm{P}_{\text {(solv) }} \stackrel{K_{1}}{\rightleftharpoons} \mathrm{H}^{+}{ }_{\text {(solv) }}+\mathrm{HP}^{-}{ }_{(\text {solv) }} ; \\
& \mathrm{HP}^{-}{ }_{\text {(solv) }} \stackrel{K_{2}}{\rightleftharpoons} \mathrm{H}^{+}{ }_{\text {(solv) }}+\mathrm{P}^{2-}{ }_{\text {(solv) }}
\end{aligned}
$$

In dependence on the acid and base strength several particles with an intermediate degree of porphyrin proton transfer can be formed. Porphyrin interaction with electron-donating solvent (Solv) such as dimethylsulfoxide (DMSO), N,N-dimethylformamide (DMF), hexamethylphosphorotriamide (HMPTA), N,N-dimethylpropyleneurea (DMPU), pyridine (Py), piperidine (Pip), etc., is based on the formation of $\mathrm{NH}$-associated molecular complexes like shown schematically by Equation (2). To react with porphyrin ligand the solvent has to combine high coordination and polarization abilities, expressed by donor number (DN) and dielectric constant $(\varepsilon)$ characteristics, respectively. Usually donor numbers of the solvent molecules should not be exceeded by acceptor number (AN) values. ${ }^{[7,17]}$

$$
\begin{aligned}
& \mathrm{H}_{2} \mathrm{P}+\text { Solv } \stackrel{K_{\text {st }}{ }^{1}}{\rightleftharpoons} \mathrm{HP}^{\delta-\cdots} \cdot \mathrm{H}^{\delta+\ldots} \text { Solv }^{\delta-} \stackrel{\text { Solv }}{=} \\
& \stackrel{\text { Solv }}{\rightleftharpoons} \text { Solv }^{\delta-\cdots} \mathrm{H}^{\delta+\cdots} \mathrm{P}^{\delta-\cdots} \cdot \mathrm{H}^{\delta+\cdots} \cdot \text { Solv }^{\delta-}
\end{aligned}
$$

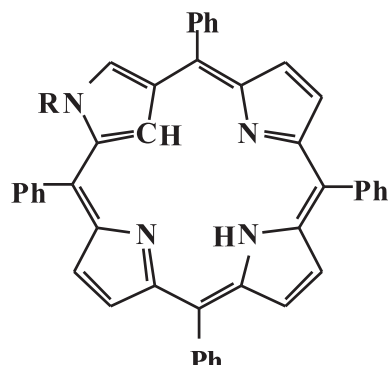

XVII b R = H; XVIII. $\mathrm{R}=\mathrm{Me}$

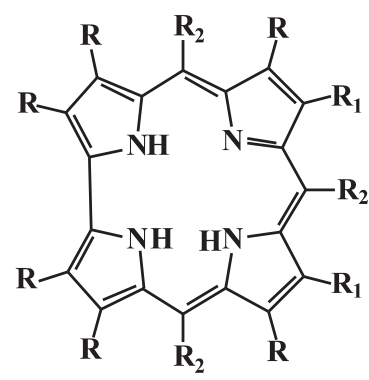

XIX. R = Me, $\mathrm{R}_{1}=\mathrm{Et}, \mathrm{R}_{2}=\mathrm{H}$; XX. $R=\mathrm{R}_{1}=\mathrm{H}, \mathrm{R}_{2}=\mathrm{Ph}$

The strength and type of porphyrin-solvent interaction depend strongly on the flatness degree of macrocyclic ligand. Porphyrin compounds with mainly planar structure do not enter to the notable chemical interaction with coordinating solvents. Moreover, as was shown by calorimetric study of dissolution processes, even specific solvation of $\mathrm{NH}$ groups of $\mathrm{H}_{2} \mathrm{P}$ coordination core is not very typical for these macrocycles. ${ }^{[23]}$ Such a conclusion was then confirmed by semiempirical calculations of deprotonation enthalpies for these molecules ${ }^{[24]}$ which have shown that their $\mathrm{NH}$ bonds are essentially covalent and not exposed to strong polarization or, moreover, to acid dissociation. Low reactivity of the coordination center of common porphyrins in solvation, acidbasic and complexation processes is easily explained from the point of view of macrocyclic effect (MCE) strategy, ${ }^{[25,26]}$ developed for porphyrins in the series of publications. ${ }^{[23,27-29]}$ MCE is a phenomenon of the spatial shielding of inner-cyclic reaction centers by their macrocyclic surrounding compared to non-macrocyclic one. ${ }^{[25]}$

Macrocyclic effect often results in quite unusual reactivity changes of the macrocycle. ${ }^{[26]}$ In the case of porphyrin molecules where inner reaction center $\mathrm{N}_{4} \mathrm{H}_{2}$ is additionally protected by $\pi$-electronic cloud, MCE is especially complicated and consists of two components. ${ }^{[29]}$ The first, steric one, has a non-chemical nature which is realized in shielding of the coordination core by $\pi$-electrons and atoms of molecular surrounding (Figure 1). The second component of macrocyclic effect is $\pi$-electronic one acting through polarization or depolarization of the $\pi$-system as a result of changes of molecular symmetry, number and 


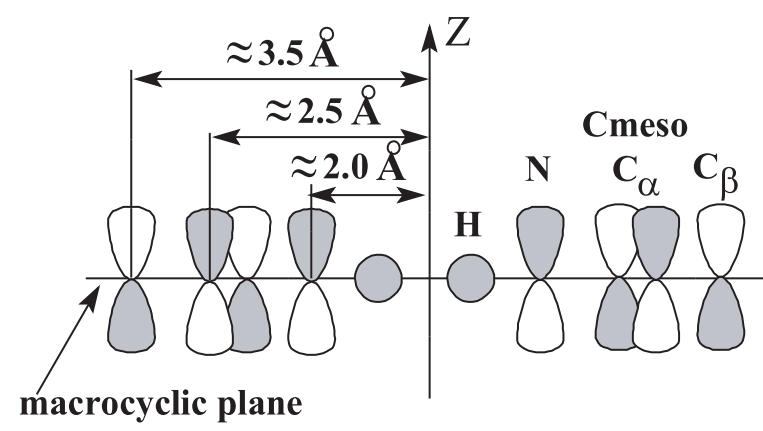

Figure 1. Coordination center shielding in porphyrin ligand.

nature of peripheral substituents, distortion or more serious modification of macrocycle. Under action of the same external factor steric and electronic components of MCE are changed asynchronously to each other causing sometimes unexpected reactivity. ${ }^{[29]}$

Surprisingly, compounds of opposite structural type of porphyrins, i.e. aromatic and highly non-planar, are able to give spectrally resolved $\mathrm{H}$-associated forms with donating organic solvents. ${ }^{[0-36]}$ In the case of highly aromatic $\mathrm{H}_{2} \mathrm{P}$ the steric component of MCE seems to effectively provide spatial shielding of the coordination core preventing any types of interaction. However, another one, $\pi$-electronic component polarizes porphyrin molecules as in $\beta, \beta$ 'fused or mesoazasubstituted ones and favors to interactions like (2). ${ }^{[21,29]}$

Interaction with solvents of common porphyrins of the third group which are macrocycles with pronounced nonplanar structure depends on the distortion degree and on the type of non-planar conformation of macrocycle. Therefore $\mathrm{H}$-associates, formed according to Equation (2), are typical only for highly $\left(\Delta \mathrm{C}_{\beta} \geq 1 \AA\right)^{*}$ distorted $\mathrm{H}_{2} \mathrm{P}$ of saddle shape (VII, XI-XIII, Figure 2,a) ${ }^{[7,37]}$

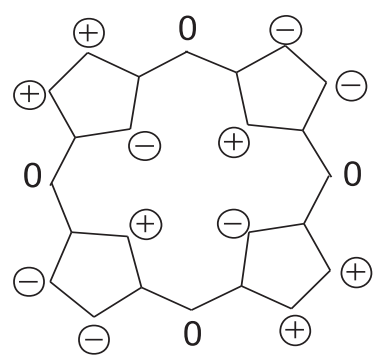

a)

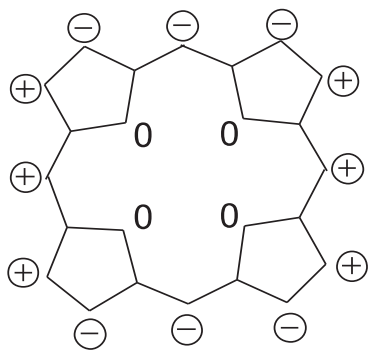

b)
Figure 2. Idealized non-planar porphyrin conformations: ${ }^{[5]}$ a) saddle; b) ruffle

The first example of porphyrin $\mathrm{H}$-associate was found by Whalley ${ }^{[30]}$ for porphyrazine I and its $\beta$-alkyl- or benzoderivatives in pyridine solution. That time associates were called "pyridinium salts" which is not quite correct first of all because the proton transfer in them is not complete. ${ }^{[21]}$ Then studies of Luk'yanets ${ }^{[31]}$ have shown that similar solvent-associated structures are formed by substituted phthalocyanine VII in solution of aliphatic amines, however stability of $\mathrm{H}$-associates and conditions in which they exist were not found. Later extended studies carried out by Petrov

\footnotetext{
${ }^{*} \Delta \mathrm{C}_{\beta}$ is a deviation of $\beta$-atoms from mean macrocyclic plane.
}

et al $^{[33,38-40]}$ have illustrated that stability of $\mathrm{H}$-associates strongly depends on the $\mathrm{NH}$-activity and macrocycle rigidity of porphyrazine ligand as well as on the nature of base and solvent system. For example, the most of highly active porphyrazine derivatives with electron-withdrawing acceptor groups $\left(\mathrm{F}, \mathrm{Cl}, \mathrm{Br}, \mathrm{NO}_{2}, \mathrm{SO}_{3} \mathrm{H}\right)$ in $\beta$-phenyl substituents or $\beta$-positions directly react with electrondonating solvents whatever their polarity and coordination ability is. ${ }^{[33,40]}$ So, ability of porphyrazine derivatives to form $\mathrm{H}$-associates (2) increases in a series of $\beta$-substituents: $\mathrm{H}-\left(\right.$ I) $<\mathrm{Ph}$ - (II) $<\left(p\right.$-Br)Ph- (III) $<\left(p-\mathrm{NO}_{2}\right) \mathrm{Ph}-($ IV $)<$ $\mathrm{Br}-(\mathbf{V}) \approx \mathrm{Cl}-(\mathbf{V I}) \cdot{ }^{[40]}$ Meantime, less polarized tetra-tertbutylphthalocyanine (VII) ${ }^{[31,39]}$ with four donating alkyl groups are able to form $\mathrm{H}$-associates only in polar media $(\varepsilon$ $\geq 30$ ) such as DMF or DMSO in the presence of basic lowpolar molecules with the higher donor numbers like Py (33.1) or DEA (50). ${ }^{[1]}$ Such a way, both factors as high polarity and donor strength have to be presented in solvent system to provide the formation of $\mathrm{H}$-complexes (2). In the presence of organic base tetrabenzoporphyrin (VIII) and its planar derivatives, which are less aromatic compounds if compared to $\mathrm{H}_{2}$ TAP (I) but more aromatic if compared to common $\mathrm{H}_{2} \mathrm{P}$, give $\mathrm{H}$-associates in very tiny amounts which are not registered in absorption spectra and are confirmed only by cross-methods, for instance, by kinetic measurements of complex formation, ${ }^{1} \mathrm{H}$ NMR spectroscopy, quantum chemical calculations. ${ }^{[7,42]}$

The main feature of the formation of porphyrazine $\mathrm{H}$-associates is an Equilibrium (2) shifted to the right. It is usually caused by low stability of the associated form with a partial proton transfer in electron-donating media. ${ }^{[33,38]}$ Therefore, many cases of destruction of the porphyrazine $\mathrm{H}$-associates are known especially in low-polar donating solvents for instance, aliphatic amines. ${ }^{[38]}$ The thermal stability of $\mathrm{H}$-associate formed by $\beta$-octaphenylporphyrazine (II) with pyridine $\left[\mathrm{H}_{2}(\beta-\mathrm{Ph})_{8} \mathrm{TAP} \cdot 2 \mathrm{Py}\right]$ in a solid determined by derivatography method was found to be quite high. In the presence of the air above $\mathrm{H}$-associate does not loose solvent molecule up to $150^{\circ} \mathrm{C} .^{[43]}$ The evaporation enthalpy of the solvent from it equals $41.2 \mathrm{~kJ} \cdot \mathrm{mol}^{-1}$. Reaction (2) for porphyrazines can be followed by UV-vis spectroscopy and characterized by the rate constant. Graphic calculations of kinetic data usually show the first or second reaction order on the base concentration depending on the nature of porphyrazine ligand. ${ }^{[33,40]}$

The aim of this paper is to compare behavior of highly aromatic and distorted $\mathrm{H}_{2} \mathrm{P}$ and their modified analogs in electron-donating media.

\section{Experimental}

Porphyrinoid compounds (VIII-IX, XI-XIII, XVII-XX) have been obtained according to published synthetic methods. ${ }^{[4-50]}$ All solvents were commercial products and purified according to known procedures. ${ }^{[51]}$ Measurements of the electronic absorption spectra including spectrophotometric titration were done on Hitachi U2000 and Hitachi U2020 spectrophotometers. Processes of monoanions (1) or H-associates (2) formation were monitored by absorption spectra in benzene-DMF, benzene-DMSO, benzene-HMPTA, benzene-DMPU, benzene-pyridine (Py), benzene-piperidine (Pip), benzene-diethylamine (DEA) and DMF-DEA solvent systems. Corresponding equilibrium constants $K_{\text {st }}$ were calculated using 
Equation (3). Number of solvent molecules (n) participating in processes (1) or (2) was estimated by graphic method from the logarithmic dependence of the indicator ratio $\left(\right.$ Ind $\left.=C_{\mathrm{H}_{2} \mathrm{P} \cdot \text { Solv }} / C_{\mathrm{H}_{2} \mathrm{P}}\right)$ from the concantration of coordination solvent $C_{\text {solv }}$ (Fiqure 3).

Emission spectra were measured on the spectrofluorimeter CM 2203. Stoks shifts are calculated according to Equation (4) where $v_{\mathrm{I}}^{\mathrm{fl}}$ and $\lambda_{\mathrm{I}}^{\mathrm{fl}}$ are, respectively, wave number $\left(\mathrm{cm}^{-1}\right)$ and wavelength (nm) of the first (adjacent) bands in fluorescence spectra; $; \lambda_{\mathrm{I}}^{\text {abs }} v_{\mathrm{I}}^{\text {abs }}$ are wave number and wavelength of the first bands in absorption spectra. ${ }^{1} \mathrm{H}$ NMR measurements were done using Bruker 200 spectrometer. Formation enthalpies of porphyrins and electric dipole moments were estimated from semi-empirical quantum-chemical calculations using AM1 and PM3 methods within Hyperchem 5.0 package.

$$
\begin{aligned}
& \mathrm{p} K_{\mathrm{st}}=\mathrm{n} \cdot \lg C_{\mathrm{Solv}}-\lg (\text { Ind }) \\
& \Delta v_{\mathrm{I}}=v_{\mathrm{I}}^{\mathrm{fl}}-v_{\mathrm{I}}^{\text {abs }}=10^{7}\left(\lambda_{\mathrm{I}}^{\text {fl. }}-\lambda_{\mathrm{I}}^{\text {abs }}\right) / \lambda_{\mathrm{I}}^{\text {fll }} \lambda_{\mathrm{I}}^{\text {abs }}
\end{aligned}
$$

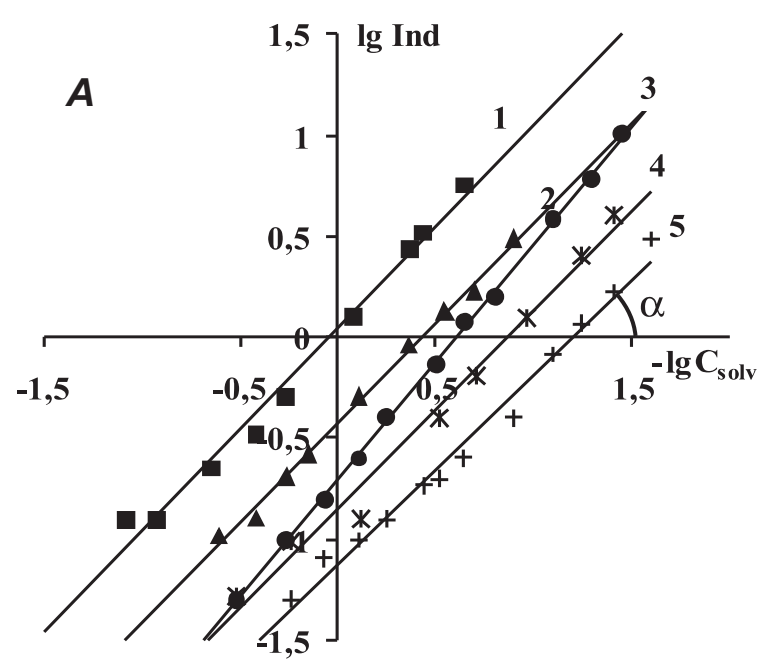

nature is applicable just for comparative studies. It varies from 0.025 for Py to 13.8 for HMPTA or about $5 \cdot 10^{2}$ times. The number of NH protons transfered to the solvent molecule in the case of XIII equals one (Figure $3, A) \cdot{ }^{[36]}$ Data obtained by us appeared to be very close to that found for benzene media. ${ }^{[36]}$

There is a strong dependence of the $\mathrm{p} K_{\mathrm{st}}$ values on the characteristics of donating solvent. However this dependence is quite complicated. The constant of $\mathrm{H}$-associate stability depends on the solvent polarity ( $\varepsilon$ or $\mu$ values) favoring to charges separation during acid-basic process, as well as on the coordination ability (for instance, DN value) showing how strong the base is. Stability of $\mathrm{H}$-associate is determined also by molar volume of the base molecule $\left(V_{\mathrm{M}}\right)$ as a characteristic of steric hindrances of its reaction center. Therefore there is no clear linearity between $\mathrm{p} K_{\text {st }}^{1}$ value and individual solvent characteristics (Figure 3, B).

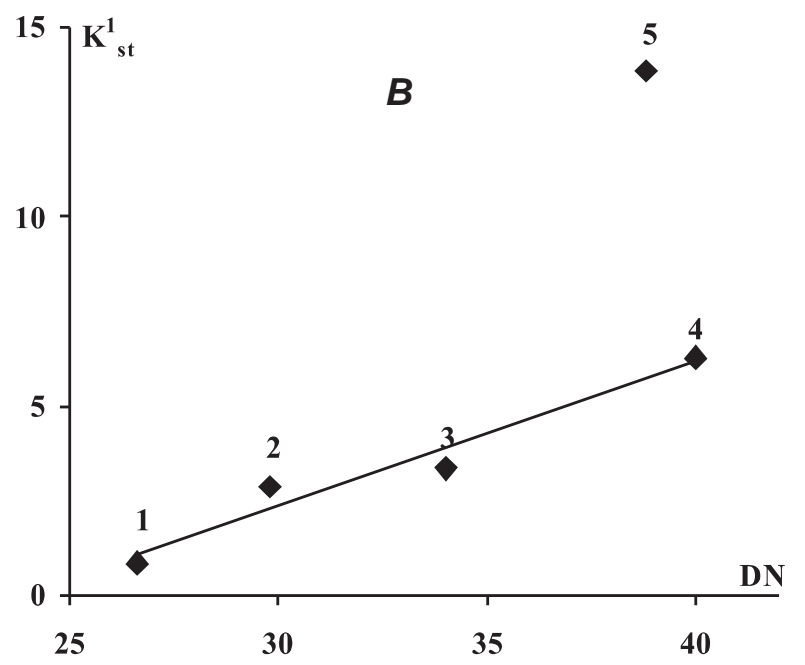

Figure 3. Graphic determination of a number of solvent molecules (n), forming H-associate with XIII according to Equation 2 ( $A$ ) and

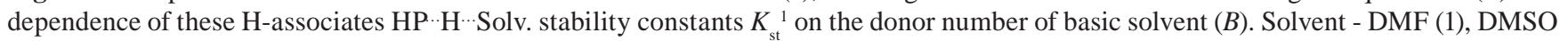
(2), DMPU (3), Pip (4), HMPTA (5).

\section{Results and Discussions}

Ability of non-planar dodecasubstituted porphyrins to form acid-basic associates with an incomplete proton transfer was found first for dodecaphenylporphyrin (XII) ${ }^{[34]}$ and its functional derivatives. ${ }^{[35]}$ About thirty five solvents of different donor-acceptor nature were taken under investigation and typical absorption spectra changes were discussed although nothing about $\mathrm{H}$-associates structure was written.

There is only one paper devoted to the stability of $\mathrm{H}$-associates $\mathrm{H}_{2} \mathrm{P}$-Solv with non-planar $\beta$-octabromo-mesotetraphenylporphyrin (XIII) where solvents were Pip, Py, DMF and DMSO in toluene media. ${ }^{[36]}$ In contrast to the reaction (2) of porphyrazines ${ }^{[21,33]}$ this one is characterized by equilibrium constant $K_{\text {st }}$ and formed $\mathrm{H}$-associates are relatively stable in solution. In our work we have broaden the number of basic solvents (Figure 3) and found that conclusions made $\mathrm{in}^{[36]}$ are correct. Within studied bases the equilibrium constant $K_{\text {st }}^{1}$ measured according $\mathrm{to}^{[36]}$ in "benzene - Solv" system because of its non-thermodynamic
$\beta$-Octabromo-meso-tetraphenylporphyrin (XIII) is one of the typical porphyrins with an expressed non-planar saddle-shaped structure combined with a small ruffling (Figure $2, b) .^{[5,45]}$ Moreover, NH-bonds in this molecule are additionally polarized by eight bromine atoms, located in $\beta$-positions. These are two main reasons for the most effective interaction of this $\mathrm{H}_{2} \mathrm{P}$ with coordinating solvents including lowdonating ones like acetone ( $\mathrm{DN}=17.0)$ as compared to other dodecasubstituted porphyrins studied. According to our spectral data H-associates stability decreases in a series of compounds: $\mathrm{H}_{2}(\beta-\mathrm{Br})_{8} \mathrm{TPP}$ (XIII, $\left.\Delta \mathrm{C}_{\beta}=1.26 ; \Delta \mathrm{C}_{\text {meso }}=0.32\right)^{*}>$ $\mathrm{H}_{2}(\beta-\mathrm{Ph})_{8}$ TPP (XII, 1.28) $>\mathrm{H}_{2}(\beta-\mathrm{Et})_{8} \mathrm{TPP}$ (XI, 1.17) $>>$ $\mathrm{H}_{2}$ TPТВP (IX, 0.77), which corresponds to the lowering to the macrocycle non-planarity determined by X-ray crystallography data ${ }^{[5]}$ and data of fluorescence spectra as an indicator of conformation of the porphyrin molecule in solution. ${ }^{[7,52]}$ In the case of with compounds distortion of the molecular structure in crystal state can be easily characterized by $\Delta C_{\beta}$ parameter (in $\AA$ ) of $\beta$-atoms deviation from mean

\footnotetext{
${ }^{*} \Delta \mathrm{C}_{\beta}$ parameter is not available for the ligand and is presented for zinc complex.
} 
Table 1. Formation of $\mathrm{H}$-associates by dodecasubstituted porphyrins and spectral shifts of bands $Q_{x}(0-0)$ in their electronic absorption spectra in basic solvents $\left(\Delta \lambda_{Q x}, \mathrm{~nm}\right)$ in dependence on the Solv characteristics, ${ }^{[41]} \mathrm{C}_{6} \mathrm{H}_{6}$ is a standart solvent.

\begin{tabular}{|c|c|c|c|c|c|}
\hline \multirow{2}{*}{ Solvent } & \multicolumn{2}{|c|}{ Solv characteristics } & \multicolumn{3}{|c|}{ Porphyrin } \\
\hline & $\varepsilon$ & $\mathrm{DN}$ & $\mathrm{H}_{2}(\beta-\mathrm{Et})_{8} \mathrm{TPP}, \mathbf{X I}$ & $\mathrm{H}_{2}(\beta-\mathrm{Ph})_{8} \mathrm{TPP}, \mathbf{X I I}$ & $\mathrm{H}_{2}(\beta-\mathrm{Br})_{8} \mathrm{TPP}, \mathbf{X I I I}$ \\
\hline Tol & $\approx 2$ & $\approx 0$ & no formation (-7) & no formation $(+2)$ & no formation $(-5)$ \\
\hline Pip & 4.3 & 40 & no formation $(+9)$ & no formation $(+2)$ & stable $(+32)$ \\
\hline DEA & 3.6 & 50 & no formation & no formation & stable \\
\hline DMSO + 5\% DEA & - & - & monoanion & monoanion & monoanion \\
\hline Py & 12.3 & 33.2 & weak interaction (+2) & weak interaction (+19) & stable $(+17)$ \\
\hline DMF & 36.7 & 26.6 & formation $(+30)$ & formation $(+27)$ & stable $(+41)$ \\
\hline DMSO & 46.7 & 29.8 & formation $(+15)$ & formation $(+31)$ & stable $(+51)$ \\
\hline DMPU & 36.1 & 34 & no formation $(+9)$ & no formation (-8) & stable $(+31)$ \\
\hline НMPTA & 30 & 38.8 & no formation $(+4)$ & no formation $(-3)$ & stable $(+28)$ \\
\hline
\end{tabular}
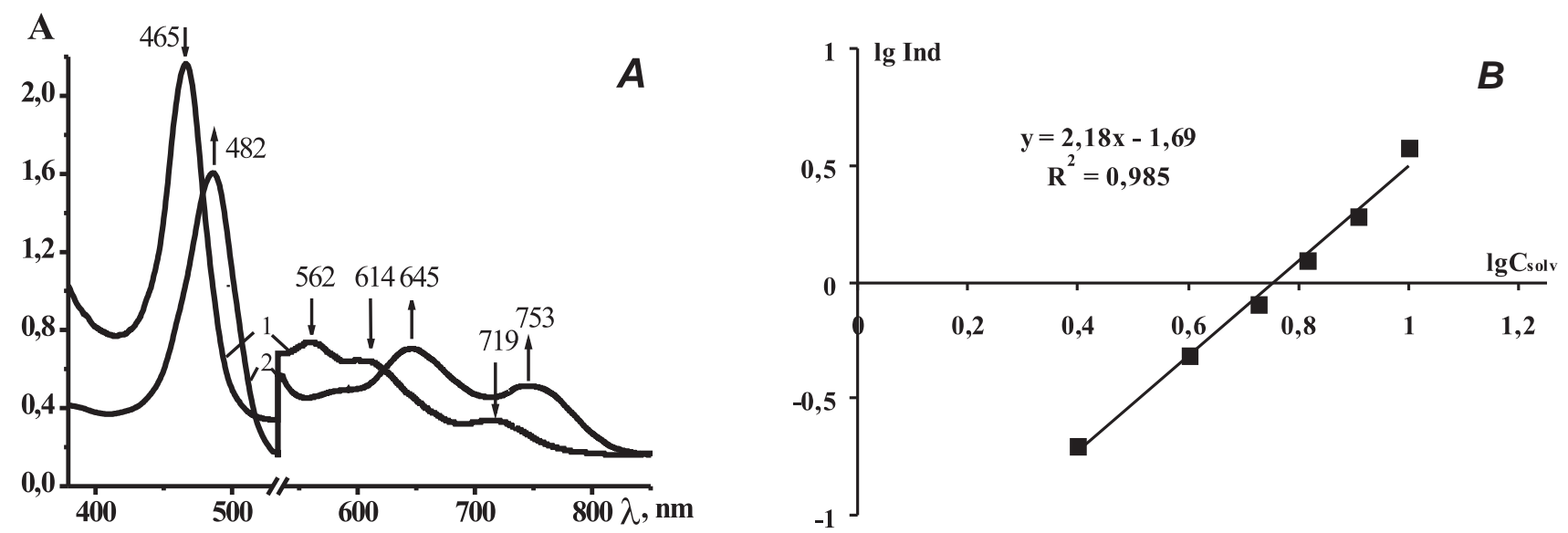

Figure 4. UV-vis spectral changes $(A)$ and graphic determination of donating solvent reaction order (tg $\alpha=2)(B)$ for XII H-associate formation in $\mathrm{C}_{6} \mathrm{H}_{6}$-DMSO system, $298 \mathrm{~K}$ : 1- molecular form of $\mathrm{H}_{2} \mathrm{P}$ in $\mathrm{C}_{6} \mathrm{H}_{6} ; 2$ - $\mathrm{H}$-associate $\mathrm{H}_{2} \mathrm{P} \cdot 2 \mathrm{Solv}$ in DMSO.

macrocyclic plane which is given in parentheses. Presumably an increase of $\mathrm{NH}$-acidity and ability of non-planar ligand to form $\mathrm{H}$-associates (2) is caused by dipole moments inherent for this kind of distorted conformation. Semi-empirical calculations by AM1 or PM3 methods show significant $\mu$-values within 1.0 - 2.9 D even for symmetrically substituted saddle porphyrins, ${ }^{[7,53]}$ although for relatively planar $\mathrm{H}_{2}$ TPP dipole moment equals zero. Even highly non-planar ruffle porphyrin conformations characterized by $\mathrm{C}_{\text {meso }}$-atoms deviation $\left(\Delta \mathrm{C}_{\text {meso }}, \AA\right)$ from mean $\mathrm{H}_{2} \mathrm{P}$ plane do not favor polarization of $\mathrm{NH}$ bonds and $\mathrm{H}$ associates formation. For example, dipole moments of ruffled tetra-meso-substituted $\mathrm{H}_{2}$ Pliketetra-iso-propylporphyrin(XIV; $\left.\Delta \mathrm{C}_{\text {meso }}=0.67 \AA\right)^{*}$, tetra-cyclo-hexylporphyrin $(\mathbf{X V} ; 0.77 \AA)$ or tetra-tert-butylporphyrin $(\mathbf{X V I} ; \approx 0.90 \AA)$ are close to zero ( $<0.1$ D by AM1 method), presumably, because of the high-symmetrical distorted structure with acidic NH-groups situated in the macrocycle plane and additionally protected by macrocyclic effect (Figure 2,b). ${ }^{[29]}$ Quantum-chemical calculations of deprotonation enthalpies also point out rather low NH-acidity of these compounds. ${ }^{[7]}$

The formation of $\mathrm{H}$-associate by non-planar common $\mathrm{H}_{2} \mathrm{P}$ is accompanied by typical spectral changes in the ab${ }^{*} \Delta \mathrm{C}_{\text {meso }}$ values not available for the ligand are presented for nickel complex, $\AA$. sorption spectra (Figure 4, $A$; Table 1). So, the long-wave $Q_{x}(0-0)$ band as well as Soret or $B$-band undergo further red shift and poorness of the spectra due to $Q$-bands degeneration and an increase of molecular symmetry. H-Associates of dodecasubstituted $\mathrm{H}_{2} \mathrm{P}$ in basic solvents can be called relatively stable only when spectral shifts $\left(\Delta \lambda_{Q x}\right)$ of the $Q_{x}$ band are higher than $15 \mathrm{~nm}$ (Table 1 ) and are not formed at all if one of two conditions - high donor strength and polarity of the solvent - is not fulfilled.

Less non-planar dodecasubstituted compounds, for instance, XI, form weaker $\mathrm{H}$-associates with two or even more solvent molecules in dependence on the media coordination properties. So, dodecaphenylporphyrin (XII) form H-complexes of 1:1 and 1:2 composition in DMSO (Figure 4) with a $K^{1,2}$ st value $0.78 \pm 0.01$. Already in a little weaker basic media (DMF) a number of solvent molecules which are in interaction with porphyrin increases up to 15. According to our unpublished results this behavior is normally reproduced in all systems where porphyrin and solvent are, relatively, too weak acid and base to form $1: 1$ or $1: 2$ stable complexes. Such a surprising number of solvent molecules found from graphic indicator dependences (Figure 4,B, see also XIX-XX H-associate formation) is explained by the situation when independent proton transfer is not justified 
thermodynamically and takes place only under formation of some kind of channels for proton transfer constructed from specially arranged solvent molecules. Analogous cases of transfer channels formation seem to be found earlier for different types of proton transfer. ${ }^{[54,55]}$ The higher number of molecules participating in the interaction with porphyrin $\mathrm{NH}$-protons corresponds to less stable $\mathrm{H}$-associates.

To estimate the NH-reactivity of common porphyrins the series of quantitative criteria as ${ }^{1} \mathrm{H}$ NMR-spectral, kinetic and quantum-chemical calculations was suggested. ${ }^{[7,20,37]}$ The first is based on the shift of NH-proton signal in ${ }^{1} \mathrm{H}$ NMR-spectrum under changing a solvent from universally solvating (US) to basic electron-donating one (BS) providing $\mathrm{H}$-associate formation (5). The value is positive, if $\mathrm{H}$-associates are formed and increases with $\mathrm{NH}$ acidity of the porphyrin (Table 2). ${ }^{[37]}$

$$
\Delta \delta_{\mathrm{NH}}=\delta_{\mathrm{BS}}-\delta_{\mathrm{US}}
$$

According to the kinetic criteria the formation of $\mathrm{H}$-complex with coordinating solvent $\mathrm{H}_{2} \mathrm{P} \cdot \mathrm{nSolv}$ is possible when the complexation reaction (6) of porphyrin ligand with a solvatocomplex of $d$-metal salt $\mathrm{MX}_{2}(\mathrm{Solv})_{\mathrm{n}-2}$ in coordinating solvents is higher $(\mathrm{BS}=\mathrm{DMSO}, \mathrm{DMF}, \mathrm{Py})$ than in moderately proton-donating media (for instance, AS $=\mathrm{AcOH})$ at the same conditions (Equation 7, Table 3).

$$
\begin{aligned}
& \mathrm{H}_{2} \mathrm{P}+\mathrm{MX}_{2}(\text { Solv })_{\mathrm{n}-2} \stackrel{-2 \text { Solv }}{\longrightarrow}\left[\mathrm{H}_{2} \mathrm{P} \cdots \mathrm{MX}_{2}(\text { Solv })_{\mathrm{n}-4}\right]^{\#} \rightarrow \\
& \rightarrow \mathrm{MP}+2 \mathrm{HX}+(\mathrm{n}-4) \text { Solv }
\end{aligned}
$$

$$
\begin{aligned}
& k_{\mathrm{v}}^{\mathrm{BS}}>k_{\mathrm{v}}^{\mathrm{AS}} \\
& \delta \Delta H_{\mathrm{f}(0-2)}=\Delta H_{\mathrm{f}(0)}-\Delta H_{\mathrm{f}(-2)}
\end{aligned}
$$

Values of $\delta \Delta H_{\mathrm{f}(0-2)}$ (8) on the formation enthalpy of porphyrin ligands $\mathrm{H}_{2} \mathrm{P}\left(\Delta H_{\mathrm{f}(0)}\right)$ and dianions $\mathrm{P}^{2-}\left(\Delta H_{\mathrm{f}(-2)}\right)$ in vacuum were calculated from semi-empirical quantumchemical data to characterize the relative stability of dianions. ${ }^{[24]}$ They are more positive for $\mathrm{NH}$-active $\mathrm{H}_{2} \mathrm{P}(\mathbf{I}, \mathbf{V}$, IX, XI-XIII) comparing to common classic ligands (X). If the chemical activity of $\mathrm{NH}$ bonds is high, the value $\delta \Delta H_{\mathrm{f}(0-2)}$ is usually positive (Figure 5). The macrocycle is $\mathrm{NH}$-active, if at least two of three above criteria are realized. ${ }^{[20]}$

These criteria are applicable for any structural group of common $\mathrm{H}_{2} \mathrm{P}^{[20]}$ however not proved to be appropriate in the case of porphyrin analogs yet excepting $\mathrm{N}$-substituted ones. ${ }^{[7]}$ Reactivity of $\mathrm{NH}$ bonds in molecules of $\mathrm{N}$-substituted porphyrin analogs is quite low as an application of quantitative criteria shows. To our knowledge at the moment only compounds from two classes of porphyrin analogs, namely, inverted porphyrins, for instance, $\mathbf{X V I I}{ }^{[15-17]}$ and corroles $(\mathbf{X I X - X X})^{[18,19]}$ are able to interact with electron-donating solvents. However the result of such interaction is principally different for these two kinds of analogs.

Corroles are found to be more $\mathrm{NH}$-active comparing to porphyrins of similar structure. If $\mathrm{H}_{2}(\beta-A l k)_{8} \mathrm{P}$ and $\mathrm{H}_{2}$ TPP (X) are inert in relation to coordinating solvents and even do not exposed to specific solvation in their media, ${ }^{[23]}$ corresponding corroles $\mathrm{H}_{3}(\beta-\mathrm{Alk})_{8}$ Cor $(\mathbf{X I X})$ and

\begin{tabular}{|c|c|c|c|c|}
\hline \multirow{2}{*}{ Porphyrin } & \multirow{2}{*}{$\mathrm{C}_{\mathrm{M}(\mathrm{OAc})_{2}} \cdot 10^{3}, \mathrm{~mol} \cdot \mathrm{l}^{-1}$} & \multicolumn{3}{|c|}{$k_{\mathrm{v}}$ and rate increase direction } \\
\hline & & $\mathrm{AcOH}$ & Py & \\
\hline $\mathrm{H}_{2}(\beta-\mathrm{Br})_{4} \mathrm{TAP}(\mathbf{V})^{[20]}$ & $\mathrm{M}=\mathrm{Zn},(0.3)$ & $0.007 \pm 0.0003$ & $930 \pm 140$ & $\rightarrow$ \\
\hline $\mathrm{H}_{2} \mathrm{TAP}(\mathbf{I})$ & $\mathrm{M}=\mathrm{Zn},(0.3)$ & $0.0087 \pm 0.0003$ & $5.79 \pm 0.04$ & $\rightarrow$ \\
\hline $\mathrm{H}_{2} \mathrm{TBP}(\mathbf{V I I I})$ & $\mathrm{M}=\mathrm{Zn},(2.6)$ & slow & $0.0069 \pm 0.0018$ & $\rightarrow$ \\
\hline $\mathrm{H}_{2}(\beta-\mathrm{Et})_{8} \mathrm{P}^{[20]}$ & $\mathrm{M}=\mathrm{Zn},(5.0)$ & $3.67 \pm 0.05$ & slow & $\leftarrow$ \\
\hline $\mathrm{H}_{2} \mathrm{TPP}(\mathbf{X})^{[20]}$ & $M=Z n,(0.48)$ & $38.6 \pm 0.90$ & slow & $\leftarrow$ \\
\hline $\mathrm{H}_{2} \mathrm{TPTBP}(\mathbf{I X})$ & $M=Z n,(2.6)$ & slow & $0.100 \pm 0.001$ & $\rightarrow$ \\
\hline $\mathrm{H}_{2}(\beta-\mathrm{Et})_{8} \mathrm{TPP}(\mathbf{X I})^{[20]}$ & $\mathrm{M}=\mathrm{Cu}(\mathrm{II}),(0.05)$ & $0.00065 \pm 0.00004$ & $1230 \pm 40$ & $\rightarrow$ \\
\hline $\mathrm{H}_{2}(\beta-\mathrm{Ph})_{8} \mathrm{TPP}(\mathbf{X I I})^{[20]}$ & $\mathrm{M}=\mathrm{Cu}(\mathrm{II}),(0.005)$ & slow & $754 \pm 20$ & $\rightarrow$ \\
\hline $\mathrm{H}_{2}(\beta-\mathrm{Br})_{8} \mathrm{TPP}(\mathbf{X I I I})$ & $\mathrm{M}=\mathrm{Zn}(\mathrm{II}),(0.22)$ & slow & fast & $\rightarrow$ \\
\hline
\end{tabular}

Table 2. Solvent influence on the position of signals $\mathrm{NH}\left(\delta_{\mathrm{NH}}\right.$, ppm) in ${ }^{1} \mathrm{H}$ NMR spectra of porphyrins.

\begin{tabular}{cccccc}
\hline Porphyrin & Solvent (US) & $\delta_{\mathrm{NH}}$ & Solvent (BS) & $\delta_{\mathrm{NH}}$ & $\Delta \delta_{\mathrm{NH}}, \mathrm{ppm}$ \\
\hline $\mathrm{H}_{2}$ TAP $(\mathbf{I})^{[20]}$ & $\mathrm{CD}_{2} \mathrm{Cl}_{2}$ & -2.07 & Py-d & -0.97 & +1.10 \\
$\mathrm{H}_{2}$ TPP $(\mathbf{X})$ & $\mathrm{CDCl}_{3}$ & -2.76 & DMSO-d $_{6}$ & -2.91 & -0.15 \\
$\mathrm{H}_{2}$ TPTBP $(\mathbf{I X})$ & $\mathrm{CDCl}_{3}$ & -1.16 & DMSO-d $_{6}$ & -1.10 & +0.06 \\
$\mathrm{H}_{2}(\beta-\mathrm{Et})_{8}$ TPP $(\mathbf{X I})^{[20]}$ & $\mathrm{CDCl}_{3}$ & -2.00 & DMSO-d & not found & + \\
$\mathrm{H}_{2}(\beta-\mathrm{Ph})_{8}$ TPP $(\mathbf{X I I})^{[20]}$ & $\mathrm{CDCl}_{3}$ & -0.90 & DMSO-d $_{6}$ & +1.00 & +1.90 \\
$\mathrm{H}_{2} \mathrm{~T}(\beta-\mathrm{Br})_{8} \mathrm{TPP}(\mathbf{X I I I})$ & $\mathrm{CDCl}_{3}$ & -1.65 & DMSO-d $_{6}$ & +0.52 & +2.10 \\
\hline
\end{tabular}

Table 3. Dependence of the rate of reaction (6), $k_{\mathrm{v}}, \mathrm{l} \cdot \mathrm{mol}^{-1} \cdot \mathrm{s}^{-1}$, between porphyrins and $\mathrm{Zn}^{\mathrm{II}}$ and $\mathrm{Cu}^{\mathrm{II}}$ acetates from donor-acceptor properties of the solvent. ${ }^{[20]}$ 


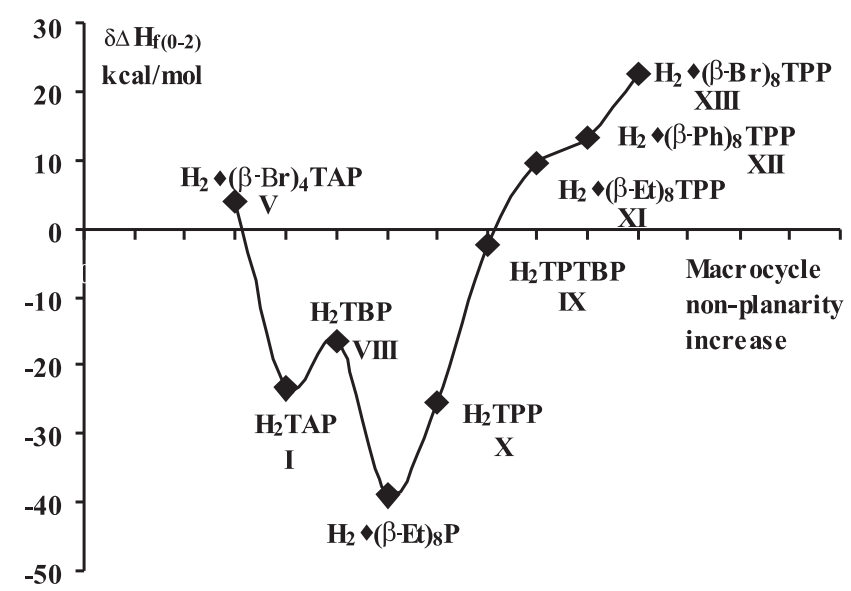

Figure 5. The relative stability of dianionic species $\mathrm{P}^{2-}, \delta \Delta \mathrm{H}_{\mathrm{f}(0-2)}$

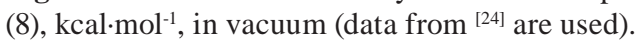

$\mathrm{H}_{3}(m s-\mathrm{Ph})_{3} \mathrm{Cor}(\mathbf{X X})$ are able to form $\mathrm{H}$-associated or even monoanionic species. ${ }^{[18,19]}$

$\mathrm{NH}$-Activity of meso-substituted molecule is higher as compared to $\beta$-octaalkylsubstituted one, presumably, because of substituents effect and different non-planarity pattern. Accordingly, $\mathrm{H}_{2}(\beta-\mathrm{Et})_{8} \mathrm{P}$ is about 500 times weaker acid in $\mathrm{NR}_{4} \mathrm{OH}-\mathrm{MeCN}$ solvent system comparing to $\mathrm{H}_{2} \mathrm{TPP}$ (see $\mathrm{p} K_{1}$ values in ${ }^{[56]}$ ). Presumably the same regularity is common for substituted corroles. So, H-associates are formed already at $\mathrm{H}_{3}(m s-\mathrm{Ph})_{3}$ Cor (XX) dissolution in polar coordinating solvent like DMF or HMPTA (Figure $6, A$ ). This behavior of meso-substituted corrole, NHactivity of which is not very high is comparable to common dodecasubstituted porphyrins of medium non-planarity and polarity (XI). More then two donating solvent molecules form $\mathrm{H}$-associates with meso-phenylsubstituted corrole $\mathbf{X X}$. The slope of the logarithmic dependence of Ind from $C_{\text {solv }}$ for titration of $\mathrm{H}_{3}(m s-\mathrm{Ph})_{3}$ Cor in benzene with HMPTA and DMF equals 6 and 11, respectively (see Figure 6, B). Possible reasons are discussed earlier.

Usually non-planarity of porphyrins in solution can be roughly characterized by the Stoks shifts of the neighbouring bands of fluorescence and absorption spectra $\Delta v_{\mathrm{I}}$ (Table 4 , Equation 4). In the case of corroles fluorescent data do not let us to make certain conclusion about non-planarity degree of the molecule because the values of Stoks shifts (Table 4) are also determined by molecule polarization. Even according to the quite rough semi-empirical calculations electric dipole moments of $\beta$ - and meso-substituted corroles XIX$\mathbf{X X}$ are about 1-2 D. Presumably macrocycle polarization is a key reason drawing solvent interactions of porphyrinoid macrocycles.

Addition of about $50 \%$ of stronger base (DEA) to DMF solution causes formation of the corrole monoanion $\mathrm{H}_{2}(m s-\mathrm{Ph})_{3}$ Cor $^{-}$accompanied by minor changes of the absorption bands structure. The same spectral picture is observed in strongly basic $0.01 \mathrm{M} \mathrm{NR}_{4} \mathrm{OH}$ solution in $\mathrm{DMF}$ (Figure 6,C). As known from literature, ${ }^{[14]}$ corrole monoanion formation makes molecule more planar and more aromatic, therefore deeper deprotonation level is not considered.

Interaction of less acidic $\beta$-alkylsubstituted corrole (XIX) with coordinating solvents does not proceed only in presence of polar weakly basic molecules like DMF (Figure $7, A$ ) and takes place just after addition of organic N-base as Pip or DEA. According to the spectral changes monoanionic species are directly formed in this solvent system. The slope of the indicator dependence (Figure $7, B$ ) is close to one.

In opposite to corroles the interaction of inverted porphyrin analogs and dipolar aprotonic solvents usually results in porphyrinoid tautomeric transformation. ${ }^{[15-17,57,58]}$ This type of solvent dependent tautomerism $a \leftrightarrows b$ was discovered by Furuta ${ }^{[15]}$ and more precisely studied by Ziegler. ${ }^{[16]}$ Later the same two tautomeric forms were found for inverted analogs with different substitution pattern. ${ }^{[57,58]}$ In our last work ${ }^{[17]}$ we have extensively studied the influence of solvent nature and found limitations for tautomer $b$ formation, which are $\varepsilon \geq 30 ; \mu>3,5 D$; DN $>25>A N$. Standard tautomeric mechanism procedure which is independent on the basic solvent nature within above limits is suggested. ${ }^{[17]}$

Tautomer $\boldsymbol{b}$ of the inverted porphyrin analogs represents some kind of special $\mathrm{H}$-associate with participation of the external NH-group in the position 2 of the macrocycle
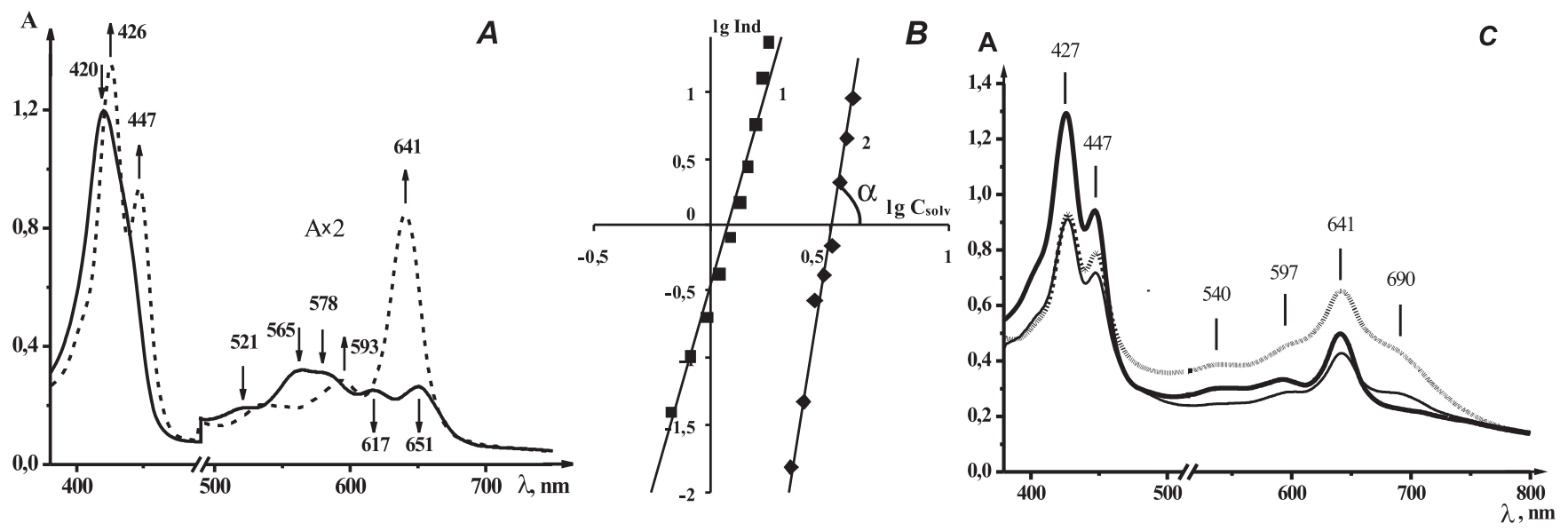

Figure 6. UV-vis spectral changes during $\mathrm{H}$-associate formation (dotted line) with $\mathrm{H}_{3}(m s-\mathrm{Ph})_{3} \mathrm{Cor}(\mathbf{X X})$ in $\mathrm{C}_{6} \mathrm{H}_{6}-\mathrm{DMF}$ system, $298 \mathrm{~K}$ $\mathrm{C}_{\mathrm{H}_{\mathrm{Cor}}}=1.9 \cdot 10^{-5} \mathrm{~mol} \cdot \mathrm{l}^{-1}(A)$, graphical determination of donating solvent order in reaction (2) (tg $\alpha \sim 6$ for HMPTA (1) and 11 for DMF (2)) $(B)$ and absorption spectra of $\mathbf{X X}$ at monoanion formation in basic media: DMF (thick solid line); 4.67 M DEA in DMF (thin solid line); $0.01 \mathrm{M}\left[\mathrm{NBu}_{4}\right] \mathrm{OH}$ in DMF (dashed line) $(C)$. 
Table 4. Characteristics of the absorption and fluorescence spectra of $\beta$ - and meso-substituted porphyrins and corroles.

\begin{tabular}{|c|c|c|c|c|}
\hline Compound & Solvent & Absorption, $\lambda_{\mathrm{I}}^{\text {abs }}, \mathrm{nm}$ & Fluorescence, $\lambda_{\mathrm{I}}^{\mathrm{fl}}, \mathrm{nm}$ & Stoks shifts $\Delta v_{\mathrm{I}}, \mathrm{cm}^{-1}\left(\Delta \lambda_{\mathrm{I}}, \mathrm{nm}\right)$ \\
\hline $\mathrm{H}_{2}(\beta-E t)_{8} \mathrm{P}$ & $\mathrm{C}_{6} \mathrm{H}_{6}$ & 623 & 624 & $26(1)$ \\
\hline $\mathrm{H}_{2} \mathrm{TPP}(\mathrm{X})$ & $\mathrm{C}_{6} \mathrm{H}_{6}$ & 645 & 651 & $146(6)$ \\
\hline $\mathrm{H}_{3}\left(\beta-\mathrm{Me}_{6} \mathrm{Et}_{2}\right) \operatorname{Cor}(\mathrm{XIX})$ & $\mathrm{C}_{6} \mathrm{H}_{6}$ & 596 & 600 & $112(4)$ \\
\hline \multirow{2}{*}{$\mathrm{H}_{3}(m s-\mathrm{Ph})_{3} \operatorname{Cor}(\mathrm{XX})$} & $\mathrm{C}_{6} \mathrm{H}_{6}$ & 650 & 670 & $459(20)$ \\
\hline & DMF & 640 & 654 & 335 (14) \\
\hline
\end{tabular}

(XVIIb). The localized molecule of donor solvent in this case stabilizes the form $\boldsymbol{b}^{[15,17]}$ Addition of tiny amount of stronger base (DEA) which is comparable to the porphyrinoid concentration to the solution of tautomer $\boldsymbol{b}$ causes immediate deprotonation of the external NH-group. Dissociation of this $\mathrm{H}$-associate is confirmed by spectrophotometric titration (Figure 8) as well as by disappearing of NH-signal at $+12.81 \mathrm{ppm}$ in ${ }^{1} \mathrm{H}$ NMR-spectra after addition of $1 \cdot 10^{-6} \mathrm{M}$ DEA to DMSO $d_{6}$ solution of $\boldsymbol{b}$. Deprotonation process is characterized by dissociation constant which equals $1.82 \cdot 10^{-7}$ in DMF. Tautomeric process and further deprotonation in
DMF-DEA media are not common for XVIII which does not possess free external NH group.

\section{Conclusions}

To form H-associates with electron-donating organic solvents which are characterized by incomplete proton transfer, porphyrins and their analogs have to possess some kind of specific structural features. The macrocyclic structure should be polarized owing either to non-planar, usually saddle, conformation or rigid $\pi$-system (porphyrazines)
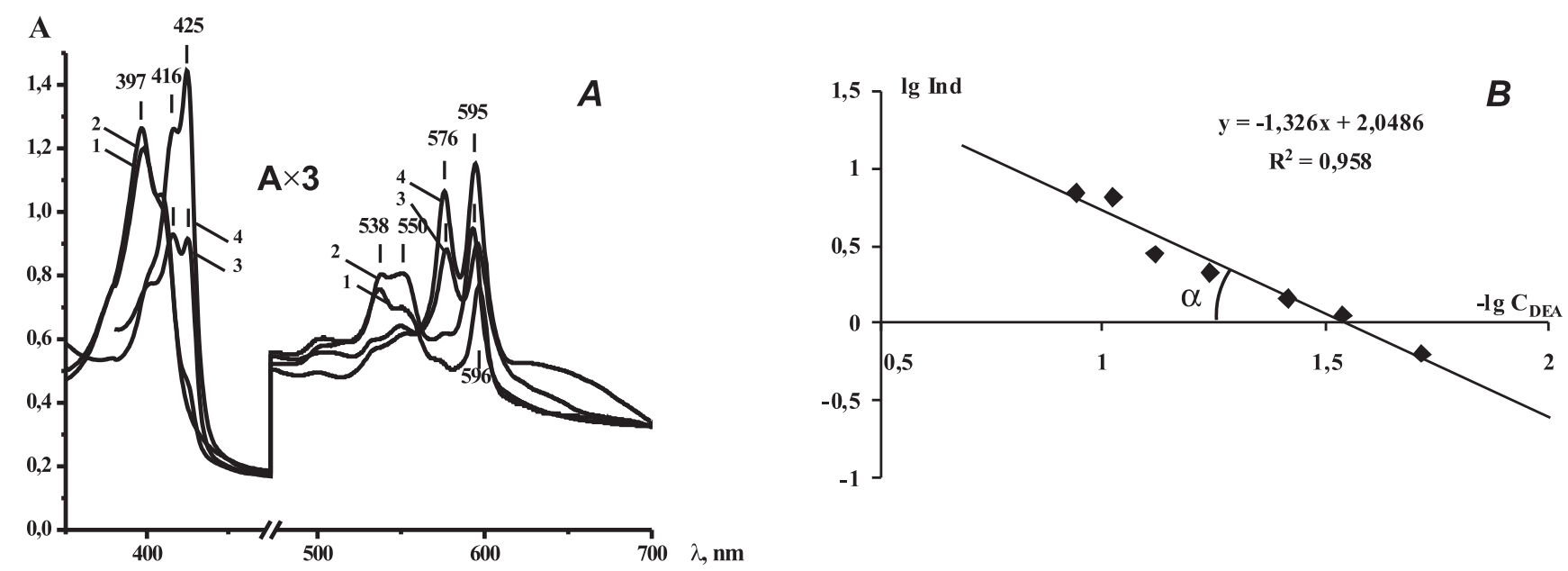

Figure 7. Absorption spectra of $\mathbf{X I X}\left(\mathrm{C}_{\mathrm{H}_{2} \mathrm{Cor}}=1.9 \cdot 10^{-5} \mathrm{~mol}^{-1}\right)$ in $\mathrm{C}_{6} \mathrm{H}_{6}(1)$, DMF (2), $0.13 \mathrm{M}$ DEA in DMF (3) and $0.01 \mathrm{M}[\mathrm{NBu}]_{4} \mathrm{OH}$ in $\operatorname{DMF}(4)(A)$; indicator dependence $\lg (\operatorname{Ind} d) \stackrel{=}{=} \lg C_{\mathrm{DEA}}$ for XIX titration with DEA in DMF media $(B)$.
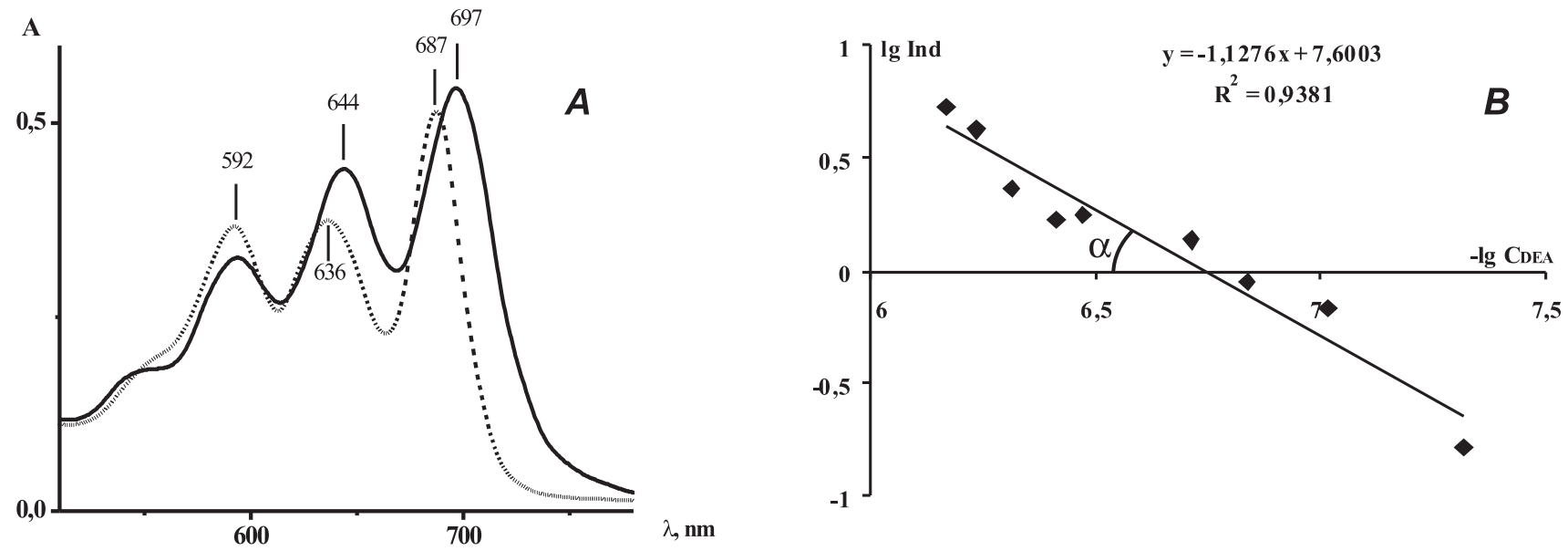

Figure 8. Absorption spectra of inverted porphyrin analog XVII in DMF (solid line, tautomer $\boldsymbol{b}$ ) and $2 \cdot 10^{-6}$ M DEA in DMF (dashed line, monoanion) $(A)$ and graphic determination of a number of NH protons splitted off ( $\operatorname{tg} \alpha \approx 1.1$ ) from the molecule XVIII in DMF-DEA solvent system $(B)$. 
or specific constitution of modified macrocycle (corroles). Combination of both high polarization and characteristics of donor solvent strongly favors the formation of $\mathrm{H}$-associated acid-basic particles.

Acknowledgements. This work was carried out under financial support of Russian Foundation for Basic Research (project № 06-03-96327) and Russian Science Support Foundation. Authors are kindly appreciated to Prof. A.S. Semeykin and Dr. P.A. Shatunov.

\section{References}

1. Senge M.O. Chem. Commun. 2006, 243-256.

2. Krygowski T.M., Cyrański M.K. Chem. Rev. 2001, 101, 5, 1385-1419.

3. Medforth C.J. NMR Spectroscopy of Diamagnetic Porphyrins, in The Porphyrin Handbook, Vol. 5 (Kadish K.M., Smith K.M., Guilard R., Eds.) New York, Academic Press, 2000, 3-80.

4. Mashiko T., Dolphin D. Porphyrins, Hydroporphyrins, Azaporphyrins, Phthalocyanines, Corroles, Corrins and Related Macrocycles, in Comprehensive Coordination Chemistry, Vol. 2 (Wilkinson G., Guilard R., McCleverty S.A., Eds.) Oxford, Permagon Press, 1987, 813-898.

5. Senge M.O. Highly Substituted Porphyrins, in The Porphyrin Handbook, Vol. 1 (Kadish K.M., Smith K.M., Guilard R., Eds.) New York, Academic Press, 2000, 239-347.

6. The Porphyrin Handbook, Vol. 2 (Kadish K.M., Smith K.M., Guilard R., Eds.) New York, Academic Press, 2000.

7. Berezin D.B. Makrotsiklicheskii Effekt i Reaktsionnaya Sposobnost' Porfirinov Razlichnogo Stroeniya (Macrocyclic Effect and Reactivity of Porphyrins with Different Structure), Diss. Doct. Chem. Sci., ISUCT, 2007, 375 p. (in Russ.)

8. Lavallee D.K. The Chemistry and Biochemistry of N-Substituted Porphyrins New York, VCH Publishers, 1987, 313 p.

9. Sessler J.L., Gebauer A., Weghorn S.J. Expanded Porphyrins, in The Porphyrin Handbook, Vol. 2 (Kadish K.M., Smith K.M., Guilard R., Eds.) New York, Academic Press, 2000, 55-124.

10. Latos-Grażyński L. Core-Modified Heteroanalogues of Porphyrins and Metalloporphyrins, in The Porphyrin Handbook, Vol. 2 (Kadish K.M., Smith K.M., Guilard R., Eds.) New York, Academic Press, 2000, 239-347.

11. Sessler J.L., Gebauer A., Vogel E. Porphyrin Isomers, in The Porphyrin Handbook, Vol. 2 (Kadish K.M., Smith K.M., Guilard R., Eds.) New York, Academic Press, 2000, 1-54.

12. Lash T.D., Colby D.A., Szczepura L.F. Inorg. Chem. 2004, 43, 5258-5267.

13. Srinavasan A., Furuta H. Acc. Chem. Res. 2005, 38, 10-20.

14. Erben Ch., Will S., Kadish K.M. Metallocorroles: Molecular Structure, Spectroscopy and Electronic States, in The Porphyrin Handbook, Vol. 2 (Kadish K.M., Smith K.M., Guilard R., Eds.) New York, Academic Press, 2000, 233300.

15. Furuta H., Ishizuka T., Osuka A., Dehima H., Nakagawa H., Ishikawa Y. J. Am. Chem. Soc. 2001, 123, 6207-6208.

16. Belair J.P., Ziegler Ch.J., Rayesh Ch.S., Modarelly D.A. J. Phys. Chem. A 2002, 106, 6445-6451.

17. Berezin D.B., Mal'tsev I.A., Semeykin A.S., Bolotin V.L. Zh. Fiz. Khim. 2005, 79, 1980-1986. (in Russ.)

18. Paolesse R., Jaquinod L., Nurco D.J., Mini S., Sagone F., Boschi T., Smith K.M. Chem. Commun. 1999, 1307-1308.

19. Berezin D.B., Karimov D.R., Mal'tseva O.V., Mitasova Yu.V. In Fifth Intern. Conference on Porphyrins and Phthalocyanines, Book of Abstracts, Moscow, 2008, 306.
20. Berezin D.B. Koord. Khim. 2007, 33, 466-470. (in Russ.).

21. Stuzhin P.A., Khelevina O.G., Berezin B.D. Azaporphyrins: Acid-base and Coordination Properties, in Phthalocyanines: Properties and Applications, Vol. 4 (Leznoff C.C., Lever A.B.P., Eds.) New York, VCH Publishers, 1996, 19-77.

22. Andrianov V.G., Malkova O.V., Berezin D.B. Kislotnoosnovnye svoistva porfirinov (Acid-Base Properties of Porphyrins), in Uspekhi Khimii Porfirinov (Advances in Porphyrin Chemistry) Vol. 3 (Golubchikov O.A., Ed.) SanktPeterburg, NII Khimii SPbGU, 2001, 107-129. (in Russ.).

23. Smirnov V.I., V'yugin A.I., Krestov G.A. Zh. Fiz. Khim. 1989, 63, 2245-2247. (in Russ.).

24. Stuzhin P.A. J. Porphirins Phthalocyanines 2003, 7, 813832.

25. Cabbines D.K., Margerum D.W. J. Am. Chem. Soc. 1969, 91, 6540-6541.

26. Yatsimirski K.B. Teor. Exp. Khim. 1980, 16, 34-40. (in Russ.)

27. Berezin M.B., Berezin B.D. Zh. Fiz. Khim. 1989, 63, 31663181. (in Russ.).

28. Klyueva M.E., Lomova T.N., Berezin B.D. Koord. Khim. 2002, 28, 793-797. (in Russ.).

29. Lomova T.N., Berezin D.B. Makrotsiklicheskii Effekt Metalloporfirinov (Metalloporphyrin Macrocyclic Effect), in Biologicheski Aktivnye Soedineniya $v$ Rastvorakh (Biologically Active Compounds in Solution) (Kutepov A.M., Ed.) Moscow, Nauka, 2001, 326-362. (in Russ.)

30. Whalley M. J. Chem. Soc. 1961, 866-869.

31. Vulfson S.V., Lebedev O.L., Luk’yanets E.A. Zh. Prikl. Spektr. 1972, 17, 903-906. (in Russ.).

32. Berezin B.D., Khelevina O.G., Gerasimova H.D., Stuzhin P.A. Zh. Fiz. Khim. 1982, 56, 1699-1703. (in Russ.).

33. Petrov O.A. Koord. Khim. 2001, 27, 449-457. (in Russ.).

34. Takeda J., Sato M. Chem. Lett. 1995, 971-972.

35. Li M., Xiao Z., Xiang H., Lu Z. Spectrochim. Acta. A. 1997, 53, 1691-1695.

36. Karmanova T.V., Gromova T.V., Berezin B.D., Semeykin A.S., Syrby S.A. Zh Obsch. Khim. 2001, 71, 803-808. (in Russ.).

37. Berezin D.B., Ivanova Yu.B., Sheinin V.B. Zh. Fiz. Khim. 2007, 81, 1986-1991. (in Russ.).

38. Petrov O.A., Chizhova N.V., Berezin B.D. Koord. Khim. 1999, 25, 218-223. (in Russ.).

39. Petrov O.A., Osipova G.V., Semeykin A.S., Berezin B.D. Koord. Khim. 2005, 31, 894-898. (in Russ.).

40. Petrov O.A. Reaktsionnaya Sposobnost' Tetraazaporfirinov $v$ Protsesse Kislotno-osnovnogo Vzaimodeistviya $i$ Molekulyarnogo Kompleksoobrazovaniya (Reactivity of Tetrazaporphyrins in the Process of Acid-base Interaction and Molecular Complex Formation), Diss. Doct. Chem. Sci., Ivanovo, ISUCT 2004, 264 p. (in Russ.).

41. Fialkov Yu.Ya. Rastvoritel' kak Instrument Kontrolya Tekhnologicheskikh Protsessov (Solvent as a Tool of Technological Process Control) Leningrad, Khimiya, 1990, 238 p. (in Russ.).

42. Berezin D.B., Toldina O.V., Kumeev R.S. Zh. Fiz. Khim. 2004, 78, 1250-1254. (in Russ.).

43. Khelevina O.G., Rumyantseva S.V., Antina E.V., Lebedeva N.Sh. Zh. Obsch. Khim. 2001, 71, 1058-1065. (in Russ.).

44. Ichimura K., Sakuragi M., Morii H., Yasuike M., Fukui M., Ohno O. Inorg. Chim. Acta. 1990, 176, 31-33.

45. Bhyrappa P., Krishnan V. Inorg. Chem. 1991, 30, 239-245.

46. Berezin D.B., Andrianov V.G., Semeykin A.S. Optika $i$ Spectrosk. 1996, 80, 618-626. (in Russ.).

47. Geier III G.R., Lindsey J.S. Organic Lett. 1999, 1, 14551462.

48. Chmielewski P.J., Latos-Grażyński L. J. Chem. Soc. Perkin Trans. 1995, 3, 503-509. 
49. Dolphin D., Johnson A.W., Leng J., Van den Broek P. J. Chem. Soc. C. 1966, 880-884.

50. Koszarna B., Gryko D.T. J. Org. Chem. 2006, 71, 3707-3717.

51. Gordon A.J., Ford R.A. The Chemist's Companion: a Handbook of Practical Data, Technics and References New York, Wiley, 1972.

52. Chirvony V.S. Pikosekundnye Fotoindutsirovannye Protsessy $v$ Molekulakh Porfirinov i ikh Kompleksakh s Nukleinovymi Kislotami (Picosecond Photoinduced Processes in Porphyrin Molecules and Their Complexes with Nucleic Acids), Diss. Doct. Chem. Sci., Minsk, IMAP NAS of Belarus' 2005, 315 p. (in Russ.).
53. Chirvony V.S., Sazanovich I.V., Galievsky V.A., Van Hoek A., Schaafsma T.J., Malinovskii V.L., Holten D. J. Phys. Chem. B 2001, 105, 7818-7829.

54. Harada R., Kojima T. Chem. Commun. 2005, 716-718.

55. Khelevina O.G., Bubnova A.S., Makarova O.N. Zh Obsch. Khim. 2006, 76, 1504-1509. (in Russ.).

56. Berezin D.B., Islamova N.I., Malkova O.V., Andrianov V.G. Zh. Obsch. Khim. 2006, 76, 997-1002. (in Russ.).

57. Morimoto T., Taniguchi Sh., Osuka A., Furuta H. Eur. J. Org. Chem. 2005, 3887-3890.

58. Shaw J.L., Garrison Sh.A., Aleman E.A., Ziegler Ch.J., Moderelli D.A. J. Org. Chem. 2004, 69, 7423-7427.

Received 4.06.2008

Accepted 5.11.2008

First publish on the web 14.03.2009 